\title{
Multidimensional model of successful aging and nursing terminologies: similarities for use in the clinical practice
}

\author{
Modelo multidimensional de envelhecimento bem sucedido e terminologias \\ de enfermagem: semelhanças para aplicação na prática clínica \\ Modelo multidimensional de envejecimiento exitoso y terminologías de \\ enfermería: semejanzas para aplicación en la práctica clínica
}

\author{
Amália de Fátima Lucena ${ }^{a, b}$ \\ Carla Argentac \\ Melissa de Freitas Luzia ${ }^{d}$ \\ Miriam de Abreu Almeida ${ }^{a}$ \\ Luciana Nabinger Menna Barreto ${ }^{b}$ \\ Elizabeth Swanson ${ }^{\mathrm{e}}$
}

How to cite this article:

Lucena AF, Argenta C, Luzia MF, Almeida MA, Menna Barreto LN, Swanson E. Multidimensional model of successful aging and nursing terminologies: similarities for use in the clinical practice. Rev Gaúcha Enferm. 2020;41(esp):e20190148. doi: https://doi.org/10.1590/19831447.2020.20190148
- Universidade Federal do Rio Grande do Sul (UFRGS), Escola de enfermagem, Porto Alegre, Rio Grande do Sul, Brasil.

- Hospital de Clínicas de Porto Alegre (HCPA). Porto Alegre, Rio Grande do Sul, Brasil.

c Universidade do Estado de Santa Catarina (UDESC). Chapecó, Santa Catarina, Brasil.

¿ Hospital Ernesto Dornelles (HED). Porto Alegre, Rio Grande do Sul, Brasil.

e University of lowa, College of Nursing. lowa City, lowa, United States of America.

\section{ABSTRACT}

Aim: To compare the domains of the Multidimensional Model of Successful Aging (MMSA) with the nursing terminologies, such as, NANDA International (NANDA-I), Nursing Interventions Classification (NIC) and Nursing Outcomes Classification (NOC), in order to find similarities among them.

Method: Cross-mapping between MMSA and nursing terminologies in two stages: individual analysis and comparison between the MMSA and the nursing terminologies, based on the mapping process rules; consensus among researchers to validate the results. Results: All NOC and NIC domains were mapped with similarity in the MMSA domains, and 12 of the 13 NANDA-I domains showed similarity to the MMSA domains. In addition, similarity was identified between MMSA and most classes of the three classifications. Conclusions: The similarity between MMSA, NANDA-I, NIC and NOC supported the idea that the MMSA framework can be used in the nursing process to qualify the nursing practice in the elderly care.

Keywords: Aging. Nursing process. Standardized nursing terminology.

\section{RESUMO}

Objetivo: Comparar domínios do Modelo Multidimensional do Envelhecimento Bem Sucedido (MMES) com as terminologias de enfermagem, NANDA International (NANDA-I), Nursing Interventions Classification (NIC) e Nursing Outcomes Classification (NOC) em busca de semelhanças entre eles.

Métodos: Mapeamento cruzado entre MMES e terminologias de enfermagem realizado em duas etapas: análise individual e comparação do MMES e terminologias de enfermagem, com base nas regras do processo de mapeamento; consenso entre os pesquisadores para validar os resultados.

Resultados: Todos os domínios NOC e NIC foram mapeados com similaridade nos domínios MMES, e 12 dos 13 domínios NANDA-I mostraram semelhança com os domínios MMES. Além disso, identificou-se semelhança entre o MMES e a maioria das classes das três classificações.

Conclusões: A similaridade entre MMES e NANDA-I, NIC, NOC fortaleceu a ideia de que o referencial do MMES pode ser entrelaçado com o processo de enfermagem para qualificar a prática de enfermagem no cuidado ao idoso.

Palavras-chave: Envelhecimento. Processo de enfermagem. Terminologia padronizada em enfermagem.

\section{RESUMEN}

Objetivo: Comparar dominios del Modelo Multidimensional del Envejecimiento Exitoso (MMES) con las terminologías de enfermería, NANDA International (NANDA-I), Nursing Interventions Classification (NIC) y Nursing Outcomes Classification (NOC) en busca de similitudes.

Métodos: Mapeo cruzado entre MMES y las terminologías de enfermería realizado en dos etapas: análisis individual y comparación de MMES con las terminologías de enfermería, basado en las reglas del proceso de mapeo; consenso entre los investigadores para validar resultados.

Resultados: Todos los dominios NOC y NIC se asignaron con similitud en los campos MMES, y 12 de los 13 dominios NANDA-I mostraron similitud con los campos MMES. Además, se identificó similitud entre el MMESy la mayoría de las clases de las clasificaciones. Conclusiones: La similitud entre MMES y NANDA-I, NIC, NOC fortaleció la idea de que el referencial del MMES puede entrelazarse con el proceso de enfermería para calificar la práctica de enfermería en el cuidado al anciano.

Palabras clave: Envejecimiento. Proceso de enfermería. Terminología normalizada de enfermería. 


\section{-INTRODUCTION}

The population aging has been increasing dramatically in recent decades and global projections are indicating that the population will continue to grow. According to the publication of the World Health Organization (WHO), the world's population for individuals over 60 years old has been estimated around 841 million people and is projected to reach two billion by 2050. This expected population growth creates a major global public health challenge, because"aging well"must become a global priority. Family members, health professions and the community resources will be expected to maintain the well-being of these individuals. In addition, there is the likelihood that a number of these individuals maybe dealing with a series of common chronic diseases ${ }^{(1)}$.

It is known that human aging is common to all and is influenced by physiological, sociological and psychological elements. But one should not consider aging as a synonym for disease. However, the advancement of age may lead to a decrease in the functional capacity of the elderly, with a decrease and even loss of autonomy and independence, and a further compromising of the individuals quality of life ${ }^{(2)}$. Thus, it is critical to evaluate if this loss of functional capacity is due to the aging process or is a consequence of the accumulation of disease. When health professionals can differentiate between these two factors, it enables them to intervene in the most effective manner.

To that end, studies have been conducted to gain a better understanding of the complexity of "successful aging" with positive results ${ }^{(3-4)}$. In the authors' opinion, one of the definitions of successful aging most encompassing of these critical multidimensional elements is: "a state wherein an individual is able to invoke adaptive psychological and social mechanisms to compensate for physiological limitations to achieve a sense of well-being, high self-assessed quality of life, and a sense of personal fulfillment even in the context of illness and disability"(3).

Based on this holistic definition of successful aging, the authors proposed and validated its conceptual framework: the Multidimensional Model of Successful Aging (MMSA), which presents three domains of health (physiological, psychological and sociological) ${ }^{(3-4)}$. Thus, MMSA allows health professionals to identify the prevalence of chronic conditions and functional limitations in the elderly at an appropriate time. This framework also enables the identification of individuals who are aging successfully, despite changes in any of the respective domains. These individuals are able to age successful due to compensatory mechanisms, which maximize the remaining intact domains.
The use of MMSA implies a gradual and continuous approach to the elderly, since the measurement of successful aging should not be performed in only one evaluation. So, the nurses in clinical practice in the care of the elderly, guided by the Nursing Process (NP) and aligned with this proposed model will be able to assess the individuals holistically.

In using this model, the nurses who assist an elderly person can select a nursing diagnosis based on data obtained from the evaluation of the different health domains, i.e., physiological, psychological and sociological. From this, nurses in concert with the individuals (clients) establish the outcomes they wish to achieve and implement interventions to improve or compensate their limited health domain, or strengthen it with resources to enhance the selected domain and thus, promote successful aging.

This is a way nurses can use the MMSA and NP together, with MMSA being a guideline for assessing the elderly and then using the NP to assist in their work with clients to maximize successful aging. Since the authors are suggesting the use of these two frameworks in this manner, it is critical the readers have information on the NP and the use of the standardized nursing language (SNL), called recently by some professionals as Advanced Nursing Process ${ }^{(5)}$.

As the term suggests, it is reflective of the NP and does encompass the use of valid assessment tools and well-defined nursing diagnoses, interventions and outcomes that are standardized and explained in scientifically based SNL within the process ${ }^{(6)}$. Various SNLs are used by nurses worldwide, however in certain parts of the world the most commonly used are NANDA International (NANDA-I) Nursing Interventions Classification (NIC) and Nursing Outcomes Classification (NOC). These classifications languages also are structured similarly to the MMSA ${ }^{(7-9)}$.

However, to date there are no published studies that have investigated the comparison between MMSA and NANDA-I, NOC and NIC (NNN). Therefore, this study seeks to answer the following question: What is the degree of similarity between NANDA-I, NIC and NOC domains and classes and the health domains proposed by MMSA? Thus, the goal of this study is to compare the domains of MMSA with the components of NANDA-I, NIC and NOC in the search for similarities between them.

\section{- METHODS}

This is a cross-mapping study, which is a process of explaining or expressing something through similar words or with the same meaning, in order to allow the comparison of data from different sources ${ }^{(10-11)}$. The use rules for this 
methodological process can be defined during its design, according to the characteristics and particularities of the studied data ${ }^{(11)}$. So, the rules established for the cross-mapping between the MMSA domains and the NANDA-I, NIC and NOC domains (NNN) in this study were:

- Compare the similarity of the meaning of each domain of MMSA (physiological, psychological and sociological) with the domains and classes of each of the NNN classifications considering the title and definition of each, as well as the diagnoses, interventions and nursing results that make them up;

- Consider words that are equal, similar or with the same meaning;

- Consider opposing concepts when mapping the MMSA with the NIC and NOC, since the interventions and the results describe a positive state that one wants to reach in a clinical situation that may be negative.

The cross-mapping was performed by seven Brazilian and North American research nurses with knowledge about the MMSA and NNN, as well as clinical experience in the elderly care and expertise about the method. It was done individually and independently and afterwards, a consensus was made between them to unify the results.

Therefore, the cross-mapping process was implemented in two different steps: first, the authors analyzed and compared the elements of the MMSA and of the NNN in search of similarities based on the mapping process rules in an individual and independent way. This phase of the study was conducted in the first semester of 2017 by Brazilian researchers, followed by a review of the findings by the North American researcher who received and resubmitted the material by e-mail.

Afterwards, the seven researchers met in person to make an attempt at consensus on the results that had been found; as a consequence of the discussion, the results were validated. This last stage was developed in the second semester of 2017 and was made through a video conference between the researchers and also at a face-to-face meeting between representatives of the Brazilian and the North American researchers at The University of lowa, United States of America.

\section{-RESULTS}

The three major domains of MMSA (physiological, psychological and sociological) were compared to each of the nursing classifications (NNN), beginning with the domains and classes. At the end of the cross-mapping, it was verified that all of the NOC and NIC domains were mapped with similarity in the MMSA domains, and 12 of the 13 NANDA-I domains showed similarity to the MMSA domains. In addition, similarity was identified between MMSA and most classes of the three individual classifications ${ }^{(3,4,7-9)}$.

The cross-mapping between the MMSA and NANDA-I are detailed in Chart 1.

The Domain 13 of the NANDA-I, Growth/Development and its two classes (Growth and Development) were not mapped in the domains of MMSA, as their titles, definitions and nursing diagnoses did not demonstrate similarity with the definitions of any of the domains within the model. Likewise, Classes 1- Sexual identity and 3- Reproduction, which make up Domain 8, were not identified with MMSA similarity.

In the mapping of MMSA with NIC, similarity was identified with all seven domains and 25 of the 30 classes of this classification (Chart 2).

The five NIC classes not mapped with the MMSA domains were J-Perioperative Care (Physiological Complex Domain); W-Childbearing Care and Z-Childrearing Care (Family Domain); A-Community Health Promotion and b-Community Risk Management (Community Domain).

The mapping between the MMSA and the NOC showed similarity with all the seven domains and with 29 of the 32 classes of this classification (Chart 3).

The three classes of NOC not mapped to the domains of MMSA were W - Family Caregiver Performance, Z - Family Member Health Status and DD - Parenting, all of them from Domain 6 - Family Health.

\section{-DISCUSSION}

The cross-mapping showed high similarity between MMSA and SNL (NNN) domains, strengthening the idea the MMSA framework can be coupled with the nursing process to improve the fragilities and /or strengthen the potentialities of the elderly. By doing this, it is possible to compensate possible physiological losses and disabilities that present themselves at this stage of life. The nurse needs to assess the intrinsic capacity of the elderly, which is a composite of all physical and mental capacities of an individual. By focusing on intrinsic capacity, i.e., the person's biological, emotional, cognitive, social, spiritual and physical status, the nurses can be better informed about the patient and plan more effectively with him/her and the family to provide care that addresses all spheres ${ }^{(12)}$.

Studies on successful aging point out that attention must be paid to the multidimensionality of the individual. Successful aging is not synonymous with absence of disease, since successful aging includes psychological, sociological 


\section{MMSA DOMAINS NANDA-I DOMAINS * \\ CLASSES *}

PHYSIOLOGICAL

Physiological components, diseases, (e.g., congestive heart failure, hip fracture, osteoporosis, osteoarthritis and cancer) and functional impairments (e.g., difficulty in standing for long periods).
1. Health Promotion:The awareness of well-being or normal- 1- Health awareness ity of function and strategies used to maintain control of and 2- Health management enhance that well- being or normality of function.

2. Nutrition: The activities of taking in, assimilating, and using 1- Ingestion nutrients for the purposes of tissue maintenance, tissue repair, 2- Digestion and the production of energy.

3- Absorption

4- Metabolism

5- Hydration

3. Elimination and Exchange: Secretion and excretion of 1-Urinary function waste products from the body.

2- Gastrointestinal function

3- Integumentary function

4- Respiratory function

4. Activity/Rest: The production, conservation, expenditure, 1-Sleep/Rest or balance of energy resources.

2- Activity/Exercise

3- Energy balance

4- Cardiovascular/ Pulmonary responses

5- Self-care

5. Perception/Cognition: The human processing system in- 1-Attention cluding attention, orientation, sensation, perception, cognition, 2- Orientation

and communication. 3- Sensation/Perception

4- Cognition

5- Communication

8. Sexuality: Sexual identity, sexual function, and reproduction. 2- Sexual function

11. Safety/Protection: Freedom from danger, physical injury, 1- Infection or immune system damage; preservation from loss; and pro- 2-Physical injury tection of safety and security.

3-Violence

4- Environmental Hazards

5- Defensive processes

6- Thermoregulation

12. Comfort: Sense of mental, physical, or social well-being 1- Physical comfort or ease.

\section{PSYCHOLOGICAL}

Psychological components (e.g., emotional vitality, coping, resilience, cognitive function).

2. Nutrition: The activities of taking in, assimilating, and using nutrients for the purposes of tissue maintenance, tissue repair, and the production of energy.

4. Activity/Rest: The production, conservation, expenditure, 1- Sleep/Rest or balance of energy resources.

5. Perception/Cognition: The human processing system in- 4- Cognition cluding attention, orientation, sensation, perception, cognition, 5-Communication and communication.

6. Self-perception: Awareness about the self.

1-Self-concept

2-Self-esteem

3-Body image

7. Role relationships: The positive and negative connections 2 -Family relationships or associations between people or groups of people and the 3-Role performance means by which those connections are demonstrated.

Chart 1 - NANDA-I domains with its definitions and classes mapped with similarity to the MMSA domains 


\begin{tabular}{|c|c|c|}
\hline MMSA DOMAINS & NANDA-I DOMAINS * & CLASSES * \\
\hline \multirow{3}{*}{$\begin{array}{l}\text { PSYCHOLOGICAL } \\
\text { Psychological } \\
\text { components (e.g., } \\
\text { emotional vitality, } \\
\text { coping, resilience, } \\
\text { cognitive function). }\end{array}$} & $\begin{array}{l}\text { 9. Coping/Stress tolerance: Contending with life } \\
\text { events/life processes. }\end{array}$ & $\begin{array}{l}\text { 1-Post-trauma responses } \\
\text { 2-Coping responses } \\
\text { 3-Neurobehavioral stress }\end{array}$ \\
\hline & $\begin{array}{l}\text { 10. Life principles: Principles underlying conduct, thought, } \\
\text { and behavioral about acts, customs, or institutions viewed as } \\
\text { being true or having intrinsic worth. }\end{array}$ & $\begin{array}{l}\text { 1-Values } \\
\text { 2-Beliefs } \\
\text { 3-Value/belief/action congruence }\end{array}$ \\
\hline & $\begin{array}{l}\text { 11. Safety/Protection: Freedom from danger, physical injury, } \\
\text { or immune system damage; preservation from loss; and pro- } \\
\text { tection of safety and security. }\end{array}$ & 3-Violence \\
\hline \multirow{6}{*}{$\begin{array}{l}\text { SOCIOLOGICAL } \\
\text { Social Components } \\
\text { (e.g., spirituality } \\
\text { and adaptation } \\
\text { through social } \\
\text { support mechanisms). }\end{array}$} & $\begin{array}{l}\text { 1. Health Promotion: The awareness of well-being or normal- } \\
\text { ity of function and strategies used to maintain control of and } \\
\text { enhance that well- being or normality of function. }\end{array}$ & $\begin{array}{l}\text { 1- Health awareness } \\
\text { 2- Health management }\end{array}$ \\
\hline & $\begin{array}{l}\text { 2. Nutrition: The activities of taking in, assimilating, and using } \\
\text { nutrients for the purposes of tissue maintenance, tissue repair, } \\
\text { and the production of energy. }\end{array}$ & 1-Ingestion \\
\hline & $\begin{array}{l}\text { 4. Activity/Rest: The production, conservation, expenditure, } \\
\text { or balance of energy resources. }\end{array}$ & 1- Sleep/Rest \\
\hline & $\begin{array}{l}\text { 7. Role relationships: The positive and negative connections } \\
\text { or associations between people or groups of people and the } \\
\text { means by which those connections are demonstrated. }\end{array}$ & $\begin{array}{l}\text { 1-Caregiving roles } \\
\text { 2-Family relationships } \\
\text { 3-Role performance }\end{array}$ \\
\hline & $\begin{array}{l}\text { 10. Life principles: Principles underlying conduct, thought, } \\
\text { and behavioral about acts, customs, or institutions viewed as } \\
\text { being true or having intrinsic worth. }\end{array}$ & $\begin{array}{l}\text { 1-Values } \\
\text { 2-Beliefs }\end{array}$ \\
\hline & $\begin{array}{l}\text { 12. Comfort: Sense of mental, physical, or social well-being } \\
\text { or ease. }\end{array}$ & $\begin{array}{l}\text { 2- Environmental comfort } \\
\text { 3- Social comfort }\end{array}$ \\
\hline
\end{tabular}

Chart 1 - Cont.

Source: Authors, 2017.

\begin{tabular}{|c|c|c|}
\hline DOMAINS MMSA & NIC DOMAINS* & CLASSES** \\
\hline \multirow{3}{*}{$\begin{array}{l}\text { PHYSIOLOGICAL } \\
\text { Physiological components, } \\
\text { diseases, (e.g., congestive } \\
\text { heart failure, hip fracture, } \\
\text { osteoporosis, osteoarthritis } \\
\text { and cancer) and functional } \\
\text { impairments (e.g. difficulty } \\
\text { in standing for long periods). }\end{array}$} & $\begin{array}{l}\text { 1. Physiological Basic: Care that supports } \\
\text { physical functioning. }\end{array}$ & $\begin{array}{l}\text { A-Activity and Exercise Management } \\
\text { B-Elimination Management } \\
\text { C-Immobility Management } \\
\text { D-Nutrition Support } \\
\text { E-Physical Comfort Promotion } \\
\text { F-Self-Care Facilitation }\end{array}$ \\
\hline & $\begin{array}{l}\text { 2. Physiological Complex: Care that supports } \\
\text { homeostatic regulation. }\end{array}$ & $\begin{array}{l}\text { G-Electrolyte and Acid-Base Management } \\
\text { H-Drug Management } \\
\text { I-Neurologic Management } \\
\text { K-Respiratory Management } \\
\text { L-Skin/Wound Management } \\
\text { M-Thermoregulation } \\
\text { N-Tissue Perfusion Management }\end{array}$ \\
\hline & $\begin{array}{l}\text { 4. Safety: Care that supports protection } \\
\text { against harm. }\end{array}$ & $\begin{array}{l}\text { U-Crisis Management } \\
\text { V-Risk Management }\end{array}$ \\
\hline
\end{tabular}

Chart 2 - NIC domains with its definitions and classes mapped with similarity to the MMSA domains 


\begin{tabular}{|c|c|c|}
\hline DOMAINS MMSA & NIC DOMAINS* & CLASSES** \\
\hline \multirow[t]{2}{*}{$\begin{array}{l}\text { PSYCHOLOGICAL } \\
\text { Psychological components } \\
\text { (e.g., emotional vitality, coping, } \\
\text { resilience, cognitive function). }\end{array}$} & $\begin{array}{l}\text { 3. Behavioral: Care that supports psychosocial } \\
\text { functioning and facilitates life style changes. }\end{array}$ & $\begin{array}{l}\text { O-Behavior Therapy } \\
\text { P-Cognitive Therapy } \\
\text { Q-Communication Enhancement } \\
\text { R-Coping Assistance } \\
\text { S-Patient Education } \\
\text { T- Psychological Comfort Promotion }\end{array}$ \\
\hline & $\begin{array}{l}\text { 4. Safety: Care that supports protection } \\
\text { against harm. }\end{array}$ & $\begin{array}{l}\text { U-Crisis Management } \\
\text { V-Risk Management }\end{array}$ \\
\hline \multirow{4}{*}{$\begin{array}{l}\text { SOCIOLOGICAL } \\
\text { Social Components (e.g., spiri- } \\
\text { tuality and adaptation through } \\
\text { social support mechanisms). }\end{array}$} & $\begin{array}{l}\text { 3. Behavioral: Care that supports psychosocial } \\
\text { functioning and facilitates life style changes. }\end{array}$ & $\begin{array}{l}\text { Q-Communication Enhancement } \\
\text { R-Coping Assistance } \\
\text { S-Patient Education }\end{array}$ \\
\hline & 5. Family: Care that supports the family. & X-Lifespan Care \\
\hline & $\begin{array}{l}\text { 6. Health System: Care that supports effective } \\
\text { use of the health care delivery system. }\end{array}$ & Y-Health System Mediation \\
\hline & $\begin{array}{l}\text { 7. Community: Care that supports the health } \\
\text { of the community. }\end{array}$ & $\begin{array}{l}\text { C-Community Health Promotion } \\
\text { D-Community Risk Management }\end{array}$ \\
\hline
\end{tabular}

\section{Chart 2 - Cont.}

Source: Authors, 2017.

* All NIC domains in its original book are identified by a number in addition to the title, which are reproduced in that table

** All NIC classes in its original book are identified by a letter in addition to the title, which are reproduced in this table.

\section{MMSA DOMAINS}

\section{PHYSIOLOGICAL}

Physiological components, diseases, (e.g., congestive heart failure, hip fracture, osteoporosis, osteoarthritis and cancer) and functional impairments (e.g., difficulty in standing for long periods).

\section{NOC DOMAINS}

1 - Functional Health: Outcomes that describe the capacity for and performance of basic tasks of life.

\section{2 - Physiologic Health:}

Outcomes that describe organic functioning.

\section{CLASSES}

A-Energy Maintenance

B-Growth \& Development

C-Mobility

D-Self-care

E-Cardiopulmonary

F-Elimination

G-Fluids \& Electrolytes

H-Immune Response

I-Metabolic Regulation

J-Neurocognitive

K-Digestion \& Nutrition

AA-Therapeutic Response

L-Tissue Integrity

Y-Sensory Function

\section{5 - Perceived Health:}

Outcomes that describe impressions of an individual's health and health care.
U-Health \& Life Quality

V-Symptom Status

Chart 3 - NOC domains with its definitions and classes mapped with similarity to the MMSA domains 


\begin{tabular}{|c|c|c|}
\hline MMSA DOMAINS & NOC DOMAINS & CLASSES \\
\hline \multirow[t]{2}{*}{$\begin{array}{l}\text { PSYCHOLOGICAL } \\
\text { Psychological components } \\
\text { (e.g., emotional vitality, coping, } \\
\text { resilience, function, cognitive). }\end{array}$} & $\begin{array}{l}1 \text { - Functional Health: Outcomes that describe } \\
\text { the capacity for and performance of basic tasks } \\
\text { of life. }\end{array}$ & B-Growth \& Development \\
\hline & $\begin{array}{l}\mathbf{2} \text { - Physiologic Health: } \\
\text { Outcomes that describe organic functioning. }\end{array}$ & J-Neurocognitive \\
\hline \multirow{4}{*}{$\begin{array}{l}\text { PSYCHOLOGICAL } \\
\text { Psychological components } \\
\text { (e.g., emotional vitality, coping, } \\
\text { resilience, function, cognitive). }\end{array}$} & $\begin{array}{l}3 \text { - Psychosocial Health: Outcomes that de- } \\
\text { scribe psychological and social functioning. }\end{array}$ & $\begin{array}{l}\text { M-Psychological Well-Being } \\
\text { N-Psychosocial Adaptation } \\
\text { O-Self-Control }\end{array}$ \\
\hline & $\begin{array}{l}\text { 4 - Health Knowledge \& Behavior: Out- } \\
\text { comes that describe attitudes, comprehension, } \\
\text { and actions with respect to health and illness. }\end{array}$ & $\begin{array}{l}\text { Q-Health Behavior } \\
\text { S-Health Knowledge } \\
\text { T-Risk Control \& Safety }\end{array}$ \\
\hline & $\begin{array}{l}5 \text { - Perceived Health: } \\
\text { Outcomes that describe impressions of an indi- } \\
\text { vidual's health and health care. }\end{array}$ & EE-Satisfaction with Care \\
\hline & $\begin{array}{l}\text { 6- Family Health: } \\
\text { Outcomes that describe health status, behavior, } \\
\text { or functioning of the family as a whole or of an } \\
\text { individual as a family member. }\end{array}$ & X-Family Well-Being \\
\hline \multirow[t]{6}{*}{$\begin{array}{l}\text { SOCIOLOGICAL } \\
\text { Social Components (e.g., spiri- } \\
\text { tuality and adaptation through } \\
\text { social support mechanisms). }\end{array}$} & $\begin{array}{l}1 \text { - Functional Health: Outcomes that describe } \\
\text { the capacity for and performance of basic tasks } \\
\text { of life. }\end{array}$ & B-Growth \& Development \\
\hline & $\begin{array}{l}3 \text { - Psychosocial Health: Outcomes that de- } \\
\text { scribe psychological and social functioning. }\end{array}$ & $\begin{array}{l}\text { N-Psychosocial Adaptation } \\
\text { P-Social Interaction }\end{array}$ \\
\hline & $\begin{array}{l}\mathbf{4} \text { - Health Knowledge } \boldsymbol{\&} \text { Behavior: Out- } \\
\text { comes that describe attitudes, comprehension, } \\
\text { and actions with respect to health and illness. }\end{array}$ & $\begin{array}{l}\text { Q-Health Behavior } \\
\text { S-Health Knowledge } \\
\text { T-Risk Control \& Safety }\end{array}$ \\
\hline & $\begin{array}{l}5 \text { - Perceived Health: } \\
\text { Outcomes that describe impressions of an indi- } \\
\text { vidual's health and health care. }\end{array}$ & EE-Satisfaction with Care \\
\hline & $\begin{array}{l}\text { 6- Family Health: } \\
\text { Outcomes that describe health status, behavior, } \\
\text { or functioning of the family as a whole or of an } \\
\text { individual as a family member. }\end{array}$ & X-Family Well-Being \\
\hline & $\begin{array}{l}7 \text { - Community Health: } \\
\text { Outcomes that describe the health, well-being, } \\
\text { and functioning of a community or population. }\end{array}$ & $\begin{array}{l}\text { BB-Community Well-Being } \\
\text { CC-Community Health Protection }\end{array}$ \\
\hline
\end{tabular}

\section{Chart 3 - Cont.}

Source: Authors, 2017.

${ }^{*}$ All NOC domains in its original book are identified by a number in addition to the title, which are reproduced in this table.

** All NOC classes in its original book are identified by a letter in addition to the title, which are reproduced in this table. 
and spirituality dimensions. In addition, the successful aging must consider what is well-being, because the elderly's self-perception is found to be a central predictive factor in experiencing successful aging. Expanding assessment beyond the disease paradigm allows to focus on the person, his / her goals, desires, and strengths to achieve those goals. This is the person-centered care, which is gaining increasing importance in the delivery of care ${ }^{(13-14)}$.

So, when nurses use the MMSA as the basis for assessment, it's possible to evaluate all the dimensions of the elderly individual and this assessment enables nurses to develop a more accurate nursing diagnosis. This assessment involves the collection of subjective and objective data and is probably the most critical step in the nursing process, because the interpretation of the collected data enable nurses to make an adequate diagnosis to the needs of the patient, as well as select the appropriate interventions to achieve the expected outcomes.

Assessment provides also the best opportunity for nurses to establish a relationship with the patient, it is both an intellectual and interpersonal nursing activity ${ }^{(7)}$. Therefore, the use of a theory or a model like the MMSA provides a cognitive map and is a very important method to assist the clinical reasoning of the nursing process. Thus, nurses have a framework that reliably guides the data collection, with the different domains and stratifies risk of the older people.

The high degree of similarity between the MMSA domains and the NANDA-I domains and classes demonstrates the elements that guide the data collection, which lead to a nursing diagnosis. The twelve domains of NANDA-I mapped with similarity to MMSA involve different dimensions of care, going beyond biomedical constructs. Several studies reinforce the need to assess the elderly from different perspectives, for example, a recent review study stated that common non-biomedical constructs associated with successful aging include engagement, optimism and/or positive attitude, resilience (including coping), spirituality and/or religiosity, self-efficacy and/or self-esteem, and gerotranscendence ${ }^{(15)}$. In addition, another study verified that successful aging had significant negative correlation with daily stress and positive correlation with resilience, therefore, the development and practical application of an intervention program to improve resilience is recommended ${ }^{(16-17)}$. Both of these studies provide rationale for nurses to assess elderly persons from a variety of points of view.

The unique domain of the NANDA not mapped with similarity in the MMSA was the Growth/Development, because this domain is about the age-appropriate increase in physical dimensions and refers to the evaluation of the children. Likewise, Sexual identity and Reproduction classes, which make up Sexuality domain, were not identified with MMSA similarity, since this approach is not applicable to the elderly. However, there was similarity with Sexual function class in this same domain of the NANDA-I.

Although, the sexuality of older people is still looking with the stereotyped views of aging and social prejudices that consider older adults asexual or disinterested in sex, growing evidence confirms that sexual desires persist in old age, with older men and women enjoying it more than ever ${ }^{(18-19)}$. These studies demonstrate that sexuality remains an important and enduring component of life and should be addressed by nursing care in the elderly.

Thus, successful aging is a complex process best described using a multidimensional model as the MMSA. In turn, all domains of NIC and NOC also were mapped with similarity in the MMSA, which corroborates the alignment of these elements. There were five NIC classes and three NOC classes that did not map with the MMSA. The title and definition of these classes did not present similarity to the definitions of the MMSA domains, since they refer to care for other age groups, such as gestation and birth care and the creation of children, as well as interventions for the improvement of health services.

The aging process can be an excellent experience if there is quality adaptation to it. In this sense, positive aging needs to be a basis of nursing care, which requires accurate nursing diagnosis, planning and implementation of interventions and, consequently, evaluation of the outcomes. In these stages of the nursing process the NANDA-I, NIC and NOC classifications are very useful, as they present the description of the elements of the nursing care in different steps, including the specificities related to the elderly. Nurses provide the front line health care for older adults in a wide variety of settings, including health promotion and preventive care in the community and acute care in hospitals. They should be integrated within multidisciplinary teams necessary to understand and address the complex issues we face in elder care, and to provide person-centered care ${ }^{(20)}$.

\section{-CONCLUSION}

The degree of similarity found in the cross-mapping between health domains proposed by the MMSA and NANDA-I, NIC and NOC domains and classes is very high, which concludes that the use of the MMSA as a basis for the assessment, provision of care and the identification of outcomes for elderly patients may be very useful to nurses.

The NANDA-I, NIC and NOC provide the structure to describe the elements of nursing practice, like diagnoses, interventions and outcomes, while the MMSA provides structure 
to guide the evaluation of the elderly and how they can achieve a successful aging. The association of this model and SNL (NNN) can facilitate the understanding and interpretation of the needs and potentialities of the elderly and thus guide a nursing quality care to achieve positive outcomes. The results of this study might be utilized in developing nursing processes that consider personal characteristics, improve successful aging and enhance older adults' quality of life.

Conflict of interest: The authors declare that there is no conflict of interest regarding the publication of this article.

\section{-REFERENCES}

1. World Health Organization (CH). World report on ageing and health: summary. Geneva: WH0; 2015 [cited 2018 Sep 11]. Available from: http://apps. who.int/iris/bitstream/10665/186468/1/WH0_FWC_ALC_15.01_eng. pdf?ua $=1 ; 2015$

2. Itha S, Argenta C, Silva MRS, Cezar-Vaz MR, Pelzer MT, Backes DS. Active ageing: necessary reflections for nurse/health professionals. J Res Fundam Care Online. 2016;8(2):4231-42. doi: https://doi.org/10.9789/2175-5361.2016.v8i2.42314242

3. Young Y, Frick KD, Phelan EA. Can successful aging and chronic illness coexist in the same individual? A multidimensional concept of successful aging. J Am Med Dir Assoc. 2009;10(2):87-92. doi: https://doi.org/10.1016/j.jamda. 2008.11.003

4. Young Y, Fan MY, Parrish JM, Frick KD. Validation of a novel successful aging construct. J Am Med Dir Assoc. 2009;10(5):314-22. doi: https://doi. org/10.1016/j.jamda.2009.01.003

5. Rabelo-Silva ER, Cavalcanti ACD, Caldas MCRG, Lucena AF, Almeida MA, Linch GFC, et al. Advanced Nursing Process quality: Comparing the International Classification for Nursing Practice (ICNP) with the NANDA International (NANDA-I) and Nursing Interventions Classification (NIC). J Clin Nurs. 2016;26(2-3):379-87. doi: https://doi.org/10.1111/jocn.13387

6. Müller-Staub M, Abt J, Brenner A, Hofer B. Expert Report on the Responsibility of Nursing. Muttenz: Schwabe AG; 2015.

7. Herdman TH, Kamitsuru S, editors. NANDA International Nursing Diagnoses: definitions and classification 2018-2020. 117 ed. New York, NY: Thieme; 2017.
8. Butcher HK, Bulechek GM, Dochterman JM, Wagner CM, editors. Nursing Interventions Classification (NIC). $7^{\text {th }}$ ed. Philadelphia, PA: Elsevier; 2018.

9. Moorhead S, Swanson E, Johnson M, Maas ML. Nursing Outcomes Classification (NOC): Measurement of health outcomes. $6^{\text {th }}$ ed. St. Louis, M0: Elsevier; 2018.

10. Lucena AF, Barros ALBL. [Cross-mapping: an alternative to data analysis in nursing]. Acta Paul Enferm, 2005;18(1):82-8. Portuguese. doi: https://doi. org/10.1590/S0103-21002005000100011

11. Moorhead S, Delaney C. Mapping nursing intervention data into the nursing interventions classification (NIC): process and rules. Nurs Diagn. 1997;8(4):13744. doi: https://doi.org/10.1111/j.1744-618X.1997.tb00468.x

12. Wang J, Boehm L, Mion LC. Intrinsic capacity in older hospitalized adults: implications for nursing practice. Geriatr Nurs. 2017;38(4):359-61. doi: https:// doi.org/10.1016/j.gerinurse.2017.06.008

13. Martinson M, Berridge C. Successful aging and its discontents: a systematic review of the social gerontology literature. Gerontologist. 2015;55(1):58-69. doi: https://doi.org/10.1093/geront/gnu037

14. Kagan SH. Balancing the problem list with an advantage inventory. Geriatr Nurs. 2017;38(2):157-9. doi: https://doi.org/10.1016/j.gerinurse.2017.03.003

15. Carver LF, Buchanan D. Successful aging: considering non-biomedical constructs. Clin Interv Aging. 2016;11:1623-30. doi: https://doi.org/10.2147/CIA.S117202

16. Byun J, Jung D. The influence of daily stress and resilience on successful ageing. Int Nurs Rev. 2016;63(3):482-9. doi: https://doi.org/10.1111/inr.12297

17. MacLeod S, Musich S, Hawkins K, Alsgaard K, Wicker E. The impact of resilience among older adults. Geriatr Nurs. 2016;37(4):266-72. doi: https://doi. org/10.1016/j.gerinurse.2016.02.014

18. Heidari S. Sexuality and older people: a neglected issue [editorial]. Reprod Health Matters. 2016;24(48):1-5. doi: https://doi.org/10.1016/j.rhm.2016.11.011

19. DeLamater J, Koepsel E. Relationships and sexual expression in later life: a biopsychosocial perspective. Sex Relatsh Ther. 2015;30(1):37-59. doi: https:// doi.org/10.1080/14681994.2014.939506

20. Morilla-Herrera JC, Garcia-Mayor S, Martın-Santos FJ, Uttumchandani SK, Campos AL, Bautista JC, et al. A systematic review of the effectiveness and roles of advanced practice nursing in older people. Int J Nurs Stud. 2016:53:290-307. doi: https://doi.org/10.1016/j.jinurstu.2015.10.010

\section{Acknowledgments:}

Conselho Nacional de Desenvolvimento Científico e Tecnológico (CNPq).

\section{- Corresponding author:}

Amália de Fátima Lucena

E-mail: afatimalucena@gmail.com

\section{Associate editors:}

Ana Karina Silva da Rocha Tanaka

Cecília Helena Glanzner 